\title{
The politicisation of UK immigration policy
}

by Julia Onslow-Cole

Immigration policy has become the political football of the western world. The tumultuous changes in UK immigration law and practice over the past two years can be ascribed to the increasing influence of political considerations in shaping policy. To a lesser extent economic factors have also played a role, however, in view of the overwhelming economic case for increased business immigration into the UK it could be argued that economic factors have not been given sufficient weight. Undeniably social and philosophical considerations have been pushed to the background. This article examines the development of UK business immigration law from 2003-04 and is a sequel to the article published by AILA in 2002 ("The state of the immigration world, the present and the future from a UK perspective", by Julia Onslow-Cole published in the Global Immigration Guide, Crossing Borders for Business).

\section{CHANGES TO THE HIGHLY SKILLED MIGRANT PROGRAMME AND THE INVESTOR CATEGORY}

I n spring 2003, the outlook for business-related immigration looked promising. The Government announced proposals to expand the highly skilled migrant programme (an innovative points based immigration category introduced in January 2002, aimed at encouraging the highly skilled to come to the UK for employment and self-employment) and introduced proposals for a new science and engineering graduate scheme - see the Chancellor's Budget Report April 9, 2003.

These proposals followed on from the Government's White Paper on immigration policy, Secure Borders, Safe Haven: Integration with diversity in Modern Britain, which it had launched in February 2002 and set out its policy of clamping down on asylum and encouraging "managed migration". The managed migration policy welcomed those who could play a full and productive part in the UK economy whilst taking firm action against those in breach of the immigration rules.

In October 2003 the changes to the highly skilled migrant programme were announced reducing the overall points required to qualify, introducing new criteria for applicants aged under 28 and taking account of graduate partners' achievements. From January 2002 to October 2003 only 3,721 successful applications had been made and the Home Office hoped that the changes would encourage more applications. The then Home Office
Immigration Minister, Beverley Hughes, stated that the Government was "committed to expanding schemes which enables us to attract unique talent to the UK and plug skills gaps in the labour market."

One month later at the IBA/AILA Global Immigration Conference in London in November 2003, Ms Hughes announced impending changes to the investor category. Applicants would be permitted to borrow the requisite $£ 1,000,000$ (which had to be invested in the UK in order to fulfil the requirements of that category) from a financial institution regulated by the Financial Services Authority. Such investors had to have at least $£ 2$ million of net assets but the changes allowed those whose assets were tied up to come to the UK. This change to the investor category, the first for almost 10 years, was prompted by Home Office consideration of comparative investor categories, particularly the one in Canada where research conclusively demonstrated that investors were making a significant contribution to the economy in the areas of employment and investment (see report from Rosalind Kunin and Cheryl Jones on the Canadian immigration investor programme).

The change to the UK immigration rules was effected in January 2004 (see Statement of Changes in Immigration Rules HC176). The Home Office press release issued with the statement of changes acknowledged the fact that the UK was competing for talented individuals with a high net worth and that the revisions to the investor rules were 
necessary to modernise the category and make it competitive with other countries.

Whilst the Home Office should be applauded for the changes to the investor category, which undoubtedly has breathed some life into this scheme, the changes are unlikely to have a major impact on the UK economy. According to Home Office records only 26 investor applications were made in 2003. Nevertheless it was an important marker emphasising the Government's commitment to inward investment in the UK.

No one attending the conference in November could have foreseen the turbulent times ahead for the Home Office and the dramatic shift in policy, which can be described as a move from one of "managed migration" to “controlled migration".

\section{ROMANIAN AND BULGARIAN VISA CRISIS}

In March 2004 a Home Office caseworker, Steve Moxon, gave a series of interviews to a leading Sunday newspaper in which he alleged that applications for permission to stay in the UK under the European Community Association Agreement were being approved with minimum, if any, checks. These "ECAA" cases were applications from self-employed persons who were nationals of European countries, which had not yet joined the European Community but had an agreement with the European Community. The agreement allowed them to make applications to come to the UK to start a business with exemption from the normal immigration requirements to employ two people and invest $£ 200,000$ in the business (see paras 211-22 Statement of Changes in Immigration Rules HC395 (as amended)). He alleged that the Home Office had adopted a system known as "BRACE" (backlog reduction accelerated entry exercise) so that ECAA applicants no longer had to provide bank statements to support their business plans. This system allegedly "rubber stamped" thousands of applications from Eastern European migrants to enter the UK.

The day after the press published Moxon's initial allegations the matter was raised by the Shadow Home Secretary, David Davis in the House of Commons. James Cameron, the British Consul in Bucharest, Romania then contacted Mr Davis and said that since October 2002 he had been complaining to the Home Office that visas had been granted in Bucharest without proper checks. It was reported that Tony Blair, the Prime Minister, had concluded a deal with Adrian Nastase, the Romanian Prime Minister, to lift visa requirements by spring 2004 for Romanians coming to Britain as a payback for Romania cutting the large numbers of asylum seekers travelling to Britain. Beverley Hughes denied she had any knowledge of the problems but Bob Ainsworth, a former Minister at the Home Office, confirmed that he had written to her directly outlining his concerns.
As a result of the scandal there was a furore in the press and the Home Secretary, David Blunkett, then suspended all applications from Romania and Bulgaria. This caused great hardship to many, including work permit holders who had been granted approval to work in the UK but were unable to obtain a visa. On April 1, 2004 Beverley Hughes, a highly respected and well regarded Minister, was forced to resign. The whole escapade resulted in a further frenzy in the media with many articles reporting the sharp increase in immigration since Labour had taken office in 1997. An often-quoted statistic from the Office for the National Statistics was that in the five years from 1998 to 2002 - the latest for which official figures are available net immigration into Britain averaged 158,000 a year and in the previous five years (1993-97) the average was just over 50,000 annually. Therefore, migration into Britain had trebled under the Labour government.

The government's position in the media was hampered by the lack of readily available research in this whole area and in particular the Home Secretary admitted in one interview that he did not know or have any figures on how many illegal immigrants were in the UK and a research fellow with the Institute for Public Policy Research confirmed this in a Sunday Times article on April 4, 2004. The report from the Home Office Economics and Resource Analysis Unit, Migration: an Economic and Social Analysis, by Glover et al commented: "It is striking how little research on migration there has been in the UK".

The furore concerning the issuance of ECAA visas came close on the heels of the terrible tragedy at Morecambe Bay where 20 Chinese cocklers (engaged in the picking of cockles from the beach) who were working illegally in the UK were drowned. The Home Office admitted that the rules concerning illegal working, and in particular penalties on illegal gang masters, should be strengthened.

Without question the Minister's resignation was media driven, and many questioned why the UK media failed to ask any of the key questions as to why officials took the policy they had with regard to the ECAA applications. Effectively in terms of overall immigration there were only modest levels of increase from citizens of Romania and Bulgaria, and they were citizens of two accession states that would be full members of the European Union within three years (see JCWI's “One sided approach to managed migration is responsible for current crisis of immigration control policies" April 6, 2004 - www.jcwi.org.uk ).

The government became very defensive about the whole issue of immigration and many argued that they allowed political opponents and the media to create myths about the scale of the problem of the threat about the new wave of immigration from the EU Accession countries. As a result of the scandal the Government commissioned a report by Ken Sutton, http://www.ind.homeoffice.gov.uk Inquiry into handling of ECAA applications from Bulgaria and Romania, and in addition there was a National Audit Office 
report (www.nao.org.uk - Visa Entry to the United Kingdom Report by the Comptroller and Auditor General, HC367, Session 2003-04, June 17, 2004. The report by Ken Sutton said that there was clear evidence that the visa system for Eastern European businessmen had been exploited. However, although he found that nearly 23,000 Romanian and Bulgarians had come to Britain on the visas between April 2002 and March 2004, he concluded that they were working rather than claiming benefits. The National Audit Office's report highlighted a number of failings in the way that the Home Office operated ECAA visa process and commented that in the Bulgarian capital of Sofia the increase in applications from 63 in 2001 to 2002 to 8034 in 2003/4 was enough to set "alarm bells ringing".

\section{BACKTRACK ON EUROPEAN ACCESSION COUNTRIES}

In the aftermath of the Romanian and Bulgaria crisis, attention in the media turned to the UK Government's position on the new accession state nationals. From May 1, 2004, Cyprus, Czech Republic, Estonia, Hungary, Latvia, Lithuania, Malta, Poland, Slovakia and Slovenia would join the European Union and European Economic Area. The UK government had originally confirmed that nationals from these countries would be given full freedom of movement rights as other nationals, and had opted not to introduce any transitional arrangements, which other countries had. In February 2004 it was announced that measures would be taken to ensure that these European nationals could not claim benefits for at least two years. However, with less than two months to go before the May 1 and no staff or facilities earmarked for the process, the Home Office took the decision to relocate caseworkers from other Home Office divisions and used them to administer a hastily devised registration scheme. In principle, all new accession country nationals ("A8 nationals) save ones from Malta and Cyprus (who were deemed to be of "less risk") would be captured by the new system.

Three sets of regulations which came into force on the May 1, 2004 created a legal requirement that A8 nationals register their employment during the first 12 months of employment in the UK, and failure to do so would result in the person working in breach of immigration law and an offence being committed by the employer. These were the The Accession (Immigration Worker Registration) Regulations 2004 SI 2004 No 1219; The Social Security (Habitual Residence) Amendment Regulation 2004 SI No 1232; and The Immigration (European Economic Area) and Accession (Amendment) Regulations SI 2004 No 1236.

The provisions also limited the right of residence for workers and work seekers from the A8 countries. The Social Security Habitual Residence Amendment Regulation added a new condition to the "habitual residence test" in social security legislation so that only persons lawfully resident in the UK would be treated as habitually resident. Together with the immigration regulations, the intention was clearly that A8 nationals would not be eligible for public funds which are dependant on satisfaction of the habitual resident test.

Without doubt this Government U-turn was media driven. The retreat from earlier promises was legal as under EU law the countries of existing members can invoke an opt out clause allowing them to impose "transitional arrangements" on the citizens of the new Member States for up to seven years. However, the government's U-turn was a surprise, and recent government announcements demonstrate that fears highlighted in the media were unfounded in that only 24,000 applications had been made since the Regulations came into force - and of these 14,400 were in the UK already.

\section{CRISIS WITH WORK PERMIT APPLICATIONS AND HIGHLY SKILLED MIGRANT PERMITS}

The immediate knock on effect of resourcing sufficient staff to deal with the new registration scheme meant that the Home Office had insufficient caseworkers to process work permit and highly skilled migrant programme applications. The system was further slowed by the introduction of a new "further leave to remain" process (Immigration (Leave to Remain) (Prescribed Forms and Procedures) Regulations SI No 2004/581; Immigration (Leave to Remain) (Fees) (Amendment) Regulations SI No 2004/580 - which introduced an additional layer of checks on individual applicants. "Turn around" times at Work Permits (UK), whose processing of in-country work permit applications had been the subject of international plaudits, increased from one week to up to eight weeks for work permit applications and 1-16 weeks for highly skilled migrant programme applications. From May until July 2004 there has been an acute crisis in the processing of applications, with many senior executives unable to travel. Unacceptable processing times have led to a chorus of business leaders and organisations including the CBI (the Confederation of Business Industry) questioning government policy in this area.

\section{REACTION TO MEDIA INTEREST IN IMMIGRATION}

In the aftermath of the visa crisis, the Prime Minister announced a "top to bottom" review of all immigration categories, and every indication is that this review will lead to a tightening of business immigration policy. The review was announced because of perceived concern about reduced confidence in the system and to focus on addressing abuse. Immigration law is highly political and the Government believes it needs to raise confidence. 
Negative media coverage continues unabated. In a recent poll 56 per cent of those interviewed felt that immigration and asylum was the most important thing facing the country (A divided nation ready to say "Enough is Enough" by Anthony King on May 26, 2004/http://news.telegraph.co.uk).

This was out of a possible 16 options including crime, the health service, Iraq and war on terrorism and Europe. The poll reported an alleged nationwide prepondence of anti-immigration sentiment, although it said that this did not translate into any generalised hostility towards immigrants or immigration community. The dominating public thinking was that Britain could not absorb many newcomers, and a general non-acceptance of the minister's views that serious labour shortages in Britain would go on necessitating high levels of immigration, especially of skilled workers, during the coming decades.

As recently as July 18, 2004 there was an article in the front page of the Sunday Express on July 18, 2004 which proclaimed that "Immigrants find another way to sneak into Britain by changing tourist status $-73,000$ cheats given work permits". The article claimed that as many 73,000 people were abusing the British work permit system and that more than half of those granted work permits came under "false pretences", in particular they originally entered the UK on short term tourist or student visas but then went into fulltime work. The article was plainly absurd since it had been widely recognised that there is little purpose in artificially forcing people to leave the UK to apply for work permits if they were in the UK in a genuinely temporary capacity.

The Conservative opposition then announced a raft of proposed measures to tighten the immigration system, and said that under their leadership they would put a limit on work permits and want to reintroduce embarkation controls for non-EU travellers to check that people were not overstaying. They also said that the right of permanent residence for anyone who has worked in the UK in a long stay immigration category would be axed.

Significantly, the government on the July 22 announced new immigration rules on switching which would become effective on the October 1, 2004 to prevent people in certain categories, including the sector-based schemes (a work permit scheme for the low skilled) to switch into work permit employment. They also announced that whilst switching may be made outside the immigration rules, the exceptional circumstances in which it could be made would be defined.

The working holidaymaker category is also under review. Many practitioners argue that the scheme, which was amended in 2003 to make it easier for working holidaymakers from commonwealth countries to come to the UK, is still operated in a discriminatory way (see For Whites only? Does the working holidaymaker skill scheme still discriminate Mahmud and Quayum and Mick Chatwin
(Tolleys Journal of Immigration Asylum and Nationality Law, Vol 18 No 2 2004). Current indications are that the rules will be tightened. In addition to adverse media reports the situation has not been helped by organisations such as Migration Watch UK, that regularly publishes negative articles on business immigration ("Unmanaged migration" May 19, 2003). Even the claims by Trevor Philips, chairman of the Commission for Racial Equality, that the goal of the multicultural society pursued by the successive governments since the 1960 s was a redundant concept because it encouraged separateness rather than asserting a core of Britishness amongst immigrants was misinterpreted by the media, which then focused on a growing concern about a minority of British Muslims who are eschewing western values and turning to extremist attitudes espoused by Islamicists such as Osama Bin Laden.

On July 22, 2004 the Asylum and Immigration (Treatment of Claimants etc) Bill received royal assent. Although this article is not examining asylum policy, it should be said that the aim of the Bill was to allegedly tackle immigration crime and to tighten up the immigration system for asylum seekers. The key provisions in the Act are a single tier asylum and immigration tribunal to consider appeals on immigration and asylum decisions and limit appeal rights and tackling crime and immigration offences. There is also provision for non EEA foreign nationals to give notice of their intending weddings to registry offices. Many commentators have complained that several provisions of the Act which have profound human rights implications have been introduced at a very late stage and without proper justification.

\section{TIGHTENING OF IMMIGRATION PRACTICE}

In addition to the policies which have been announced, there has been a clear tightening of Home Office practice on business related applications across the board. Practitioners have noticed, for example, that work permit applications are being closely scrutinised and discretion is rarely being exercised in the applicant's favour. There has been a noticeable hardening in the attitude of the Immigration Service.

When the freeze on visa applications from Bulgaria and Romania was eventually lifted, the Home Office imposed curbs on two schemes for seasonal workers, namely the seasonal agricultural workers scheme and a similar scheme operating for the hospitality and food processing industry. In addition, the government is clamping down on illegal workers and has tightened up the documents which employers can rely on to claim a defence to such a charge of illegal working (Immigration (Restrictions on Employment) Order SI No 2004/755). There have been a number of high profile raids on establishments across England. Furthermore, there have been high profile investigations of educational establishments and a tightening of rules relating to students. In July the government announced it was considering tightening the 
immigration rules for Imams and priests to come to work in the UK as ministers of religion.

\section{ECONOMIC CASE FOR IMMIGRATION}

The economic case for increased business immigration remains well founded. Immigration is a key driver of the labour market. In a comparative study by Gail McLaughlan and John Salt from the Migration Research Unit of University College London - Report to the Home Office, March 2002: Migration Policies Towards Highly Skilled Foreign Workers - the UK's highly skilled migration scheme was widely regarded as the most successful and responsive in the world. The report compared schemes from nine other countries and concluded that the UK had moved faster and further than any other country - with the exception of Australia and to a lesser extent Canada - in attracting the highly skilled. In a study by Christine Dustman on migration in the UK in 2003 - Migrants in the UK, Dustman et al - it was found that the overall adverse impact of immigration on unemployment and wages had been negligible and the study showed a small positive correlation between inward migration and rising domestic wage. Information from Labour Force Survey Summer (June to August 2003, Quarterly Supplement, October 2003 UK No 23) confirms that the UK work force has continued to realise employment and wage gains during a period of rising inward migration. The Department for Education suggests that the changing skill demands over the next 10 years will make it imperative that employers have highly skilled workers.

In summary, Government data show that the trends going forward reveal a significant growth in employment in all higher level occupations and therefore employers will face a growing need for high skilled labour which cannot be met by the existing population. In July the Centre for Economics and Business Research reported that jobs in the City of London would reach a record 339,000 and would have completely recovered from the bursting of the dot.com bubble in 2001-02. In the same month the Office for National Statistics released a report which concluded that by the early 2050 s the 80 plus population would peak at close to 7 million with the population as a whole being about 65 million.

\section{CONCLUSION}

On July 21, 2004, there was a report in the press that the Governments policy advisors were calling for a reduction in immigration to the $\mathrm{UK}$ and in particular to London. Further negative press comments followed the announcement in August 2004 that Steve Moxon, the official who started the visa investigation, had been sacked (Sunday Times, August 1, 2004).

It seems unlikely that the media stance on immigration will change in the immediate future, and therefore the government must stand firm against reacting to this and formulating policy in the midst of highly political debates. Without doubt one of the key issues the government will be judged as the long term is its economic success, and the economic case for immigration is beyond doubt. Recent Government initiatives, in particular to embrace business leaders to champion immigration policies are very positive. An immense amount of work has been done in this regard by the Employability Forum (see www. employabilityforum.co.uk ) in co-operation with the Home Office. Business leaders are gradually appreciating the importance of immigration, and recognise that they should rightly act as the spokespersons for a managed migration policy.

The government skills strategy paper published in July 2003 set out commitments to help employers and in particular skills of the domestic workforce, but without migration as a complimentary measure to this objective the UK will lose its place as a high skilled innovative economy. Without a progressive and generous business immigration policy, the UK will be left at the starting line in the race for talent.

\section{Julia Onslow-Cole}

A senior partner and head of CMS Cameron McKenna's global immigration business practice; immediate past chair of the IBA's Immigration Committee and current Member of Council; chair of the United Nations and Other World Organisations Committee and Secretary of the IBA's Educational Trust.; an Expert and Advisory Panel Member to the Office of the Immigration Services Commissioner; former Secretary of the Immigration Law Practitioners' Association; Member of the American Immigration Lawyers Association and The UK Association of European Law; Fellow of the Society of Advanced Legal Studies; a contributing coeditor of Butterworths Immigration Law Service, Sweet and Maxwell's loose-leaf Immigration Law and Practice, and Macdonald's Immigration Law and Practice. 